Pamiętnik Literacki 2012, 4, s. 27-43
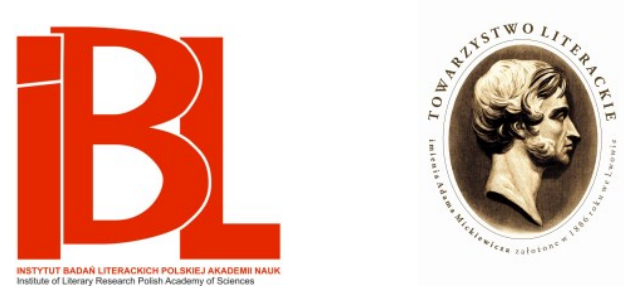

Nowelistyczny tryptyk Stefanii Chłędowskiej

- zagubione ogniwo polskiego „bowaryzmu”?

Aneta Mazur 
Pamiętnik Literacki CIII, 2012, z. 4

PL ISSN 0031-0514

ANETA MAZUR

(Uniwersytet Opolski)

\section{NOWELISTYCZNY TRYPTYK STEFANII CHŁĘDOWSKIEJ - ZAGUBIONE OGNIWO POLSKIEGO „BOWARYZMU”?}

Proza polska drugiej połowy XIX wieku sytuuje się na mapie XIX-wiecznego weryzmu jakby na pograniczu: pomiędzy moralizująco-dydaktyczną prozą wiktoriańską, ,poetyckim” realizmem niemieckim oraz ,uduchowionym” obszarem powieści rosyjskiej. Najbardziej oczywista i świadoma filiacja z realizmem (naturalizmem) francuskim była w praktyce poddana silnej presji psychologicznych oporów etycznych oraz wyraźnym zabiegom korekcyjnym. Zaświadcza o tym fakt, iż polski realizm XIX stulecia nie ma właściwie rodzimej wersji Pani Bovary Gustave'a Flauberta, dzieła będącego słynną matrycą „,bowaryzmu”'. Sporadyczne są także - poza studiami Bogdana Mazana oraz nie publikowaną pracą Grzegorza Przepiórki - wnikliwsze rozpoznania badaczy na tym obszarze ${ }^{2}$. Nie zastą-

1 Abstrahując od „plagiatowej” powieści A. Sy gi ety ń ski e g o Na skałach Calvados (1884), niewolniczo opartej na fabule Flaubertowskiej, z domieszkami Zolowskiego naturalizmu, w tekstach realistów pojawiają się, oczywiście, sporadyczne nawiązania, obejmujące poszczególne wątki bądź postaci; do najczęściej przywoływanych - obok Na skałach Calvados (postać Berty Boudard) - należą Cham i Nad Niemnem E. O r z e s z k o w e j (Franka Chomcówna, Emilia Korczyńska), Lalka B. P r u s a (Izabela Łęcka, Wokulski) oraz Na normandzkim brzegu M. K o n o p$\mathrm{n}$ i cki ej (Yvetta chorująca na mal du lointain). Flaubertowskie motywy znaleźć można także w prozie późniejszej (np. u G. Zapolskiej, W. S. Reymonta, S. Żeromskiego czy A. Mańkowskiego), są to jednak filiacje dość odległe. Z kolei miano „polskiego Flauberta”, jakie zyskał W. Berent, nie miało związku z wątkami bowarystowskimi, lecz z warsztatem pisarskim artysty.

2 Zob. M. Gło w i ń s k i, ,Cham”, czyli pani Bovary nad brzegami Niemna. W zb.: ,Lalka” i inne. Studia w stulecie polskiej powieści realistycznej. Red. J. Bachórz, M. Głowiński. Warszawa 1992. - K. S z c z u k a, Nuda buduaru. W zb.: Nuda w kulturze. Red. P. Czapliński, P. Śliwiński. Poznań 1999. - E. Gra c z y k, O postaciach bowarycznych w powieściach Elizy Orzeszkowej. W zb.: Tworczestwo Elizy Ożeszko w estieticzeskom prostranstwie sowriemiennosti. Ried. S. F. M us i j e n k o. Grodno 2011. Najbardziej zasłużonym ,bowarystą” jest z pewnością B. Mazan, autor szeregu artykułów, które wpisują się w ambitny projekt badacza anonsowany przed laty jako „całościowe opracowanie poświęcone bowaryzmowi polskich pozytywistów i modernistów” oraz „opracowanie [...] ujęcia przez modernistów samej formuły bowarystowskiej” (B. M a z a n, Bowaryzm w literackich transpozycjach polskich modernistów. W zb.: Literatura Młodej Polski. Między XIX a XX wiekiem. Red. E. Paczoska, J. Sztachelska. Białystok 1998, s. 15. Zob. też tego autora: Literackie transpozycje doświadczenia bowarystowskiego w miłości. W zb.: Sztuka a erotyka. Materiaty Sesji Stowarzyszenia Historyków Sztuki, Łódź, listopad 1994. Red. T. Hrankowska. Warszawa 1995; Cechy stylowe mieszczańskiej egzystencji $i$ kultury $w$ świetle postaw bowarystowskich z przetomu wieków. W zb.: Mieszczaństwo i mieszczańskość w literaturze polskiej drugiej połowy XIX wieku. Red. E. Ihnatowicz. Warszawa 2000; Maria Konopnicka, „Morze odeszło”- bowaryzm, mistycyzm, 
pi ich, oczywiście, również niniejsza propozycja interpretacyjna; dorzuci może jednak parę ciekawych szczegółów.

Trop bowarystowski w prozie Stefanii Chłędowskiej (1850-1884) jest tym bardziej intrygujący, iż twórczość tej zapomnianej nowelistki nie funkcjonuje, w przeciwieństwie do słynnego dzieła Flauberta, w powszechnej świadomości literackiej ${ }^{3}$. Pośmiertne, dwutomowe wydanie krótkich form prozatorskich Chłędowskiej $(1885)^{4}$ przeszło bez większego echa. Niemniej jednak już ówcześni recenzenci unisono doceniali w autorce "subtelną nowelistkę psychologiczną" ${ }^{\text {, }}$ specjalizującą się w „,wybornych” portretach osobowości kobiecych ${ }^{6}$. „Swój świat kobiety [...] zna [ona] dokładnie i przedstawia z talentem charaktery kobiet" chwaliła Ostoja ${ }^{7}$.

z wielką subtelnością studiuje spóźnioną miłość w Babim lecie, bezsilny upadek w Historii

tajemnica. W zb.: Małe prozy Orzeszkowej i Konopnickiej. Red. I. Wiśniewska, B. E. Obsulewicz. Lublin 2010). Łódzki badacz wymienia bądź omawia pokrótce teksty, gdzie występują „,bowarystowskie" postaci (Na skałach Calvados, Nad Niemnem, Lalka, Chtopi, a także utwory Konopnickiej, Zapolskiej, Żeromskiego, I. Dąbrowskiego), więcej materiału odnajdując w prozie młodopolskiej. Interesująca jest praca magisterska G. P r z e p i ó r k i pt. Bowaryzm w literaturze polskiej (powstała w 150-lecie Pani Bovary, pod kierunkiem prof. A. Czyża w Akademii Podlaskiej w Siedlcach w 2007; publikacja fragmentu: Bowaryzm. Teoria zjawiska w nowym świetle. „Ogród” 2010, nr 1/2), gdzie wnikliwej analizie zostały poddane warianty polskiego bowaryzmu w Lalce Prus a, Nad Niemnem Orzeszkowej, Nocach $i$ dniach M. Dąbrowskiej, Dziewczętach z Nowolipek P. Gojaw iczyński ej, Cudzoziemce M. Kuncew i c zow ej oraz w cyklu opowiadań Moje pierwsze samobójstwo J. P i $1 \mathrm{c} \mathrm{h}$ a (Autorowi uprzejmie dziękuję za udostępnienie mi tekstu pracy).

3 O krytycznoliterackiej twórczości Chłędowskiej piszę w artykule Stefania Chłędowska (1850-1884) - krytyk niespetniony (w zb.: Dyskursy krytycznoliterackie 1764-1918. Wokót „Stownika polskiej krytyki literackiej"'. Red. G. Borkowska, M. Rudkowska. Warszawa 2010), natomiast inne wątki jej nowelistyki omawiam w szkicu Stefania Chtędowska - zapomniana nowelistka (w druku). O twórczości pisarki zob. też W. Ło z i ń s k i, Stefania Chtędowska. W: S. Chłę d o w$\mathrm{s} \mathrm{k}$ a, Nowele i szkice literackie. T. 1. Lwów-Warszawa 1885. - P. C h m i e l o w s k i: Chtędowska. Hasło w: Wielka encyklopedia powszechna ilustrowana. T. 11. Warszawa 1893, s. 703; Zarys najnowszej literatury polskiej (1864-1897). Kraków-Petersburg 1898, s. 295. - A. B a r, Chtędowska. Hasło w: Polski stownik biograficzny. T. 3. Kraków 1937. - I. W y c z a ń s k a, Stefania Chtędowska. W zb.: Literatura polska w okresie realizmu i naturalizmu. Red. J. Kulczycka-Saloni, H. Markiewicz, Z. Żabicki. T. 2. Warszawa 1966. „Obraz Literatury Polskiej XIX i XX Wieku”. Seria 4.

4 C hłę d o w s k a, op. cit., t. 1-2. Dalej do Nowel i szkiców literackich odsyłam skrótem N. Pierwsza liczba, po łączniku, wskazuje tom, następne - stronice.

5 Wielka ilustrowana encyklopedia powszechna $\mathrm{G}$ u t e n b e r g a. Na stronie: www.gutenberg. czyz.org/word,11258 (dostęp: 2 VII 2011). Zob. też Ł o z i ń s k i, op. cit., s. VIII: „Figury wprowadzone $\mathrm{w}$ akcję miały wiele psychologicznego interesu, były śmiało a zarazem misternie modelowane, znać w nich było fine touche dłoni artystycznej, subtelność i zarazem energię". - B a r, op. cit., s. 306: ,jej nowele [...] nie odznaczały się wprawdzie odpowiednio opracowaną kompozycją, wnikały jednak w psychologię postaci". - C h m i e l o w s k i, Zarys najnowszej literatury polskiej, s. 295: „umiejętnie potrafiła najprostszymi środkami wywołać wrażenie nawet tragiczne”.

6 Zob. [A n o n i m], Silva rerum. „Kronika Rodzinna” 1885, nr 16, s. 509: „Obrazy podpatrzone z życia kobiet szczególniej są wyborne". Dlatego nieco krzywdząca wydaje się opinia M. M a rc j a n (Nowela. Hasło w: Stownik literatury polskiej XIX wieku. Red. J. Bachórz, A. Kowalczykowa. Wrocław 1991, s. 617), która zbywa utwory Chłędowskiej deprecjonującym, bądź co bądź, określeniem ,noweli salonowych”.

${ }_{7}$ O s t oj a [J. S a w i c k a], Nowości literackie. „Kraj” 1885, nr 37, s. 25. Ostoja zarzucała jednak Chłędowskiej anachroniczność bohaterek kobiecych, sprowadzonych do ,potulnych trusiątek i bezsilnych kochanek” (ibidem). „Cicha, pracowita maszyna” to bohaterka Panny Ludwiki - noweli, która w rankingu pochwał krytycznych zajmuje bezkonkurencyjnie miejsce pierwsze. 
nie-bohaterów; zna dziką miłość południowej dziewczyny, zna nawet fertyczne pokojowe, a w cichych, pracowitych maszynach umie podsłuchać uderzenie serca ${ }^{8}$.

Niektórzy krytycy wiązali te inklinacje z odległą tradycją literacką - autorka „lubi szare tło codziennego życia i na tym tle pysznie haftuje przede wszystkim miłość, która subtelnością odcieni przypomina wytworną szkołę dawniejszych francuskich romansów"'. Inni jednak podkreślali właśnie (korzystne lub zgubne, w zależności od ich orientacji ideowej) pokrewieństwo z bieżącą literaturą francuską, która „widocznie uderzyła jej [tj. Chłędowskiej] do głowy” ${ }^{10}$. Czy wśród tych, którzy zawrócili Chłędowskiej w głowie, był - obok wielokrotnie wymienianego przez krytyków Alphonse'a Daudeta - także Flaubert? ${ }^{11}$ Trop „bowarystowski” uwidoczniają zwłaszcza jej portretowe studia obyczajowo-psychologiczne. Już Chmielowski, zauważając nieudolność pisarki w portretowaniu ludzi prostych, oceniał, że nowele Chłędowskiej, „odznaczające się miękkością i delikatnością rysunku, subtelnością spostrzeżeń i dowcipem słowa, najlepiej przedstawiały ludzi zdenerwowanych, chorobliwych, goniących za wrażeniami dla zagłuszenia nudy, lekkomyślnych, nieszczęśliwych" ${ }^{12}$. Sąd ten powtórzyła badaczka współczesna: „najbardziej bliskie prawdzie życiowej są postacie kobiet »z wyższych sfer « - kobiet niedołężnych, przesubtelnionych, ginących z nudów wśród zbytku i nieróbstwa" ${ }^{13}$. Kto wie, czy o zbieżnościach nowelistyki Chłędowskiej z Paniq Bovary nie myślała też zgorszona Lisicka, wytykając autorce mylne wyobrażenia o życiu towarzyskim, według których „,należy bezustannie brnąć w mętnych wodach zakazanych uczuć i zdrożnych stosunków, kończących się zwykle na samobójstwie jako n aj s zl a c het n i ej s z y m wyjściu z fałszywego położenia" ${ }^{14}$. Ponieważ Chłędowska tylko w jednym wypadku wprowadziła motyw samobójstwa bohaterki (w noweli Lionora, gdzie nie jest to wyjście z fałszywego położenia damy z towarzystwa, lecz rozpaczliwy akt namiętnej i porzuconej dziewczyny z ludu, włoskiej „Ulany”), zachodzi podejrzenie, iż Lisicka nawiązywała do losów Emmy Bovary, widząc w nich wzorzec (inspirację) dla fabuł w utworach galicyjskiej pisarki.

Już wczesne nowele Chłędowskiej z lat siedemdziesiątych XIX stulecia zdradzają motywy czy epizody być może Flaubertowskiej proweniencji. W Pierwszej

8 Ibidem.

9 Ibidem. Warto pamiętać o zamiłowaniach Chłędowskiej do XVIII-wiecznej psychologii literackiej; Nowej Heloizie J.-J. Rousseau publicystka poświęciła najwięcej miejsca w swoim szkicu Nowe i dawne kierunki romansu (1878).

10 „Fałszywy blask francuskiego realizmu widocznie uderzył jej do głowy” - wyrokowała zgorszona A. L i s i c k a (A. M. L., ,, Nowele i szkice literackie” przez Stefanię Chłędowska. „Przegląd Powszechny" 1885, z. 7, s. 134).

${ }^{11}$ Nowelistka uważała autora Pani Bovary za ,jednego z największych artystów-pisarzy naszego wieku”, choć nie aprobowała jego prozy w pełni: „Dla takiego artysty człowiek, świat, natura są to rzeczy podrzędne; człowiek stworzony jest dla sztuki, a nie sztuka dla człowieka, iluzja staje się ważniejsza od prawdy, portret od modelu, wyraz od samego uczucia" (S. C h ł ę d o w s k a, Noweliści. W: Szkice literackie. T. 1. Lwów-Warszawa 1885, s. 111).

${ }^{12} \mathrm{Chmielowski,} \mathrm{Chłędowska,} \mathrm{s.} \mathrm{703.} \mathrm{Także} \mathrm{Łoziński} \mathrm{(op.} \mathrm{cit.,} \mathrm{s.} \mathrm{VIII)} \mathrm{podkreślał}$ wyrafinowanie kreacji Chłędowskiej: „taka w tym była ciepła kolorystyka, taka morbidezza [tj. skrajna delikatność i miękkość, zmysłowa subtelność, zniewieściałość] obok cech szerokiego literackiego i estetycznego wykształcenia".

13 W y c z a ń s k a, op. cit., s. 486.

14 A. M. L., op. cit., s. 134-135. 
próbie, melodramatycznej historii miłosnej, pojawia się dygresja o spleenie bohaterki, młodej i zagubionej żony starca:

jest taka choroba, która się zwie znudzeniem. Maleńka choroba rodzi się wśród zdrowia i mocą ziewnięcia spędza uśmiech z ust najświeższych, obejmuje nas wśród czterech ścian, gnieździ się wszędzie, w deseniu obicia, w fałdach firanek, na każdym kwiatku dywana [!]. Siadamy na kanapie, już jest nieprzyjaciel przy nas; spędza nas z siedzenia, każe podchodzić do okna i patrzeć na chmury, gonić błękitny obłok. A wśród chmur znowu siedzi potwór, każe nam z obłoków na powrót tęsknić do ziemi, bo aniołowie w niebie nudzić się muszą, śpiewając wiecznie „Hosanna”. [N-1 82-83]

Jeszcze ciekawszą postać spotykamy w Świetnych aliansach; pojawia się tam znudzona żona prowincjonalnego lekarza (!), tęskniąca za niezwykłym życiem arystokracji. Kreacja bohaterki, prowadzącej tu pierwszoosobową narrację retrospekcyjną, wydaje się wręcz świadomą polemiką z Panią Bovary. Przywołując swoje odczucia z pierwszych lat małżeństwa, okresu kryzysu i zwątpienia: „Już dłużej nie wytrzymam tej ciszy, tej jednostajności - tego życia tak podrzędnego, pospolitego, nieznośnego!... To nie dla mnie...” (N-1 284), heroina dokonuje równocześnie surowej samooceny z perspektywy czasu:

Przez kilka lat po ślubie nudziłam się okropnie - nie wystarczała mi miłość mego męża, a raczej szacunek jego i przywiązanie, bo to człowiek poważny, zajęty pracą i obowiązkiem, który się na romansach nie rozumiał [...]. Dzieci nie miałam, zajęcia nie umiałam sobie stworzyć; rozrywką, jakiej mi mogło nastręczyć towarzystwo małomiejskie, gardziłam z wysokości urojonego piedestału. [...]

Zdrowie moje zaczęło cierpieć na tej moralnej chorobie głowy i serca, straciłam prawie chęć do życia, a gdy się samej siebie pytałam, czemu jestem nieszczęśliwa, nie umiałam znaleźć odpowiedzi. Ale budzić się codziennie do tego samego życia, do jednostajności nie przerwanej żadnym wypadkiem, wydawać na obiad, szyć sobie suknie, chodzić na targ i do kościoła; i znowu nazajutrz do kościoła i na targ, to wprowadzało mnie w rozpacz, [...] obowiązków dopełniałam jak pańszczyzny, jakby w letargu albo we śnie lunatycznym. [N-1 274-275]

Arystokracja! Zdawałoby się, że to słowo było zbyt wielkie albo moje usta zbyt małe, aby je wymówić! Byłam jeszcze tak dziecinną, tak mało świat znałam, że wierzyłam w ludzi z innej gliny ulepionych [...]. [N-1 277]

Jednak o stricte bowarystowskich fabułach wypada mówić dopiero w przypadku swoistego tryptyku, jaki tworzą trzy dłuższe studia nowelistyczne (opowiadania) z lat osiemdziesiątych, należące do ostatniego, najbardziej dojrzałego etapu pisarstwa Chłędowskiej: Impresjonistka, Z historii nie-bohaterów oraz Babie lato. Bohaterki tych trzech utworów brną w „,zakazanym” kierunku z niejednakową determinacją, lecz wszystkie przedstawiają świat kobiecych marzeń o miłości, których realizacje (bądź ich próby) kończą się dla nich w sposób upokarzający lub destrukcyjny. Jeśli zjawisko bowaryzmu sprowadzić do kilku najczęściej wyliczanych aspektów, fabularnych lub dyskursywnych - małżeńskie rozczarowanie i zdrada, wyalienowanie z codzienności i znudzenie, pragnienie ucieczki od prozy życia, zdeterminowane (melodramatycznymi) schematami literackiej proweniencji, głód zmysłowych i nastrojowych wrażeń, jak również ironiczna, odautorska demaskacja żałosnej tragikomedii życia ${ }^{15}$ - każda z trzech nowel podejmuje inny $\mathrm{z}$ wymienionych aspektów oraz inaczej go realizuje.

${ }^{15} \mathrm{M}$ a z a n (Bowaryzm w literackich transpozycjach polskich modernistów, s. 13-14, 24, 26) skłonny jest widzieć w bowaryzmie rozległy „paradygmat kulturowo-literacki i światopoglądowy”, 
Impresjonistka, według określenia samej autorki, prezentuje ,ciekawy problemat psychologiczny" (N-1 414), jakim jest bowarystowski głód doznań symulujących rzeczywistość ${ }^{16}$. U małej markizy sięga on stopnia monomanii i przybiera osobliwą formę nieustannego poddawania się zmiennej fali bodźców zewnętrznych:

Zależało od drugich, [...] czym była chwilowo [...]. Była jak to zmienne zwierzątko, co przybiera barwy przedmiotu, do którego się zbliża, samo przez się bezbarwne, szare. [...]

[...] pojęcie jej własnej nicości [...] uderzało ją i obejmowało tak przejmującym żalem [...]. Trzeba się było koniecznie zagadać, zagłuszyć... [N-1 407]

Nie wiedziała dobrze, czego jej potrzeba; czasem byłaby rada, aby życie to odmieniało się bezustannie, aby się kręciło i wirowało między przeciwnymi biegunami; czasem znowu niestałość, niepewność męczyła ją okropnie. [N-1 410-411]

Stan „kobiety żądnej wrażeń”, zagubionej między niedosytem a nadmiarem, znudzeniem a pragnieniem spokoju, przypomina wprawdzie bardziej huśtawkę spleenowca Chateaubrianda ${ }^{17}$ niż „męską” determinację Emmy, a dziecięce roztrzepanie oraz dziwaczny sposób bycia czynią z Filomeli ,,istotkę zabawną” i ,duszyczkę niespokojną, błędną" - jak nie omieszka ze złośliwą ironią komentować narrator (N-1 405, 407, 410) - którą Bovary z pewnością nie była. Niemniej jednak iście bowarystowskie jest u bohaterki Chłędowskiej wyznanie: „Ja tak lubię romanse!" (N-1 419), jak również pragnienie sztucznych podniet -

Znała naturę w karykaturze, z opisów w niektórych romansach poetycznych i z dekoracyj opery, przy świetle gazowym - wrażenia wielkie a spokojne, które sprawia widok tego, co Bóg stworzył, były jej nieznane, marzyła o innych, bardziej silnych i nerwowych.

[...] Szlochanie głośne, pełny i ponury głos dzwonów, posępny ceremoniał pogrzebowy - to wszystko poruszało jej krew, pobudzało nerwy [...]. [N-1 402-403]

Zakochawszy się pod wpływem przypadkowego impulsu, impresjonistka układa swój romans pod wtór podrażnionej wyobraźni i wyuczonej lektury:

miała zawsze pełno takich cudownych drabinek w zapasie i teraz zarzuciła jednę wysoko, w wielką próżnię... po niej będzie się wspinać w górę, po nowe, nie znane dotąd wrażenia... $[\mathrm{N}-1416]$

„rudyment i wyróżnik XIX-wieczności europejskiej”, pojęty jako „zestaw problemów (tematów) światopoglądowych i artystycznych", wśród których badacz jako konstytutywne dla bowaryzmu wymienia: dychotomię podmiotowość/przedmiotowość, ideał szczęścia, marzenie o zmianie miejsca (dalekie, egzotyczne lub fikcyjne przestrzenie), poetycko-romantyczną i sentymentalno-nastrojową wyobraźnię, rozczarowanie, znużenie, nieokreślone tęsknoty, nudę, melancholię, egzystencjalne wyobcowanie i gorycz istnienia. Prze pi ó rk a we wspomnianym artykule Bowaryzm. Teoria zjawiska w nowym świetle (s. 92, 97, 114-115) - nawiązując m.in. do określeń M. Janion i A. Barciszewskiej - mówi o „sztucznej literalizacji życia”, „steatralizowaniu”, „zmaterializowaniu” lub „ułomnej próbie odzwierciedlenia [marzeń] w rzeczywistości”, proponując następujący model bowaryzmu, wypływającego z ustawicznych impulsów książkowych: „lektura - marzenie - maska (poza) - lektura”, oraz taką jego definicję: „Zjawisko postromantyczne, charakteryzujące się ucieczką od rzeczywistości w sferę iluzji, w wyniku oddziaływania tekstów kultury, z immanentnym zakwestionowaniem takiej postawy w dziele literackim (deziluzja)". Autor akcentuje przewagę impulsów „romansowych” nad „zmysłowymi” w motywacjach Emmy Bovary.

${ }_{16}$ Bohaterka Impresjonistki stanowi swego rodzaju pendant do prawdopodobnie wcześniejszej Pani Luizy E. Orzes s k ow ej (1876).

${ }_{17}$ Stąd też paradoksalne skojarzenia, powtarzające romantyczne clichés René: „Prawie zazdrościła wdowie... [...] W cierpieniu musi być rozkosz pewna - tak myślą szczęśliwi, chorujący na melancholię" (N-1 402-403). 
Trzy dni przeleżała na kanapce, jakby pijana jakimś marzeniem bez treści. To była chwila, w której wszystkie romanse kiedykolwiek przeczytane w życiu, rzucone jak ziarno w głąb duszy, nagle rozkwitły, rozrosły się. Przyswoiła je sobie na własność. Były to dawne, zapomniane wrażenia, które teraz odżyły, cudze zdania o miłości, które wzięła za własne przekonania.

Rzecz dziwna, nie czuła nawet koniecznej potrzeby widzenia Mieczysława - wystarczało jej chwilowe wrażenie, którego doznała, mianowicie pieściła się tą myślą, co uczuje, gdy on przyjdzie? [N-1 418]

Na marginesie warto zauważyć, iż passus robi wrażenie nie tylko semantycznej, ale i językowej ${ }^{18}$ parafrazy Flaubertowskiej narracji. Markiza w większym stopniu niż Emma zadowala się imaginacyjnym surogatem rzeczywistości, ale podobnie jak Emma ponosi klęskę w konfrontacji z faktami. Mieczysław nie jest ani uwodzicielskim Rudolfem, ani mdłym, bezwolnym Leonem, jest doświadczonym przez życie, rozsądnym i myślącym literatem; tylko że w swym braku empatii i w swej solenności przypomina Karola, a egocentryzm artysty nie pozwala mu dostrzec słabej istoty, złaknionej uczucia. W pewnym sensie i on staje się obiektem ironicznej, bowarystowskiej diagnozy: odniósłszy sukces w kraju, pisarz wyrusza do Ameryki, bo „stary świat nie wystarcza do poznania człowieka w zupełności” (N-1 427). Spontaniczna, bardziej impulsywna od Emmy impresjonistka posiada jednak zmysł autoanalizy i samokrytycyzmu, co sprawia, że jej dramat ma charakter świadomy i bardziej tragiczny niż utrzymana do końca w tragikomicznej konwencji rola pani Bovary. Melancholia, w jaką markiza ostatecznie popada, ukazana zostaje obiektywnie i bez auktorialnej ironii ${ }^{19}$. Jedynie jej śmierć - wprawdzie nie samobójcza, ale samobójstwo przypominająca - nosi wszelkie znamiona literackiego melodramatu oraz swoistej farsy. Tonacja złośliwej czy szyderczej ironii, przypisywana narracji Flauberta, u polskiej nowelistki znajduje odpowiednik w jawnych komentarzach, z dystansem oceniających bohaterkę (w mniejszym stopniu - jej otoczenie).

Bała się po prostu przestać mówić, czując coraz to silniejszy przypływ nicości czarnej, bezdennej w głębi serca. [...] Nareście powiedziała sobie, że trzeba się poddać przeznaczeniu, przestała wychodzić... [...]

[...] Zaczynał się w niej proces zwykły, tym razem straszny, proces negacyjnej myśli, która odrabiała rzeczywistość i odbierała całej przeszłości barwę po barwie... Dochodziła do przekonania, że była niczym, że nie kochała nawet nigdy swego bohatera, że u niej wszystko to było imaginacją, głupstwem. Ogarniała ją niedola i żal niezmierny. W godzinach melancholii robiła sobie sama wrażenie liszki chciwej, pracowitej, która pożarła całą zieloność listka, na którym żyła, i nie miała czym karmić się już nadal. [N-1 428-429]

musiała umrzeć, jak gaśnie lampa [...], umrzeć po prostu... z braku wrażeń...

Wszyscy dziwili się bardzo temu końcowi, który miał w sobie coś tragicznego. Zdawało się, że śmierć, rzecz poważna, rzecz tak filozoficzna, nie powinna dotykać ludzi śmiesznych... Jakiekolwiek były jej wady, świat lubił małą markizę - żal mu było tej ładnej zabawki, tego poliszynela, który się złamał w jego ręku... [N-1 430]

${ }^{18}$ Chodzi raczej o składniową intonację niż o styl - ten u Chłędowskiej w istocie jest, jak stwierdzał C h m i e lo w s k i (Chłędowska; Zarys najnowszej literatury polskiej), często bez wyrazu: prosty, schematyczny, niekiedy wręcz nieudolny.

19 Skłonności melancholiczne bohaterki anonsowane są też wcześniej, i to ciekawym szyfrem genderowym: „Czynem żyła w przyszłości, pragnieniem cofała się w przeszłość i obrabiała w myśli to, co już należało rzeczywistości. Tym sposobem życie jej jak robota Penelopy było tylko fantastycznym haftem, który zarabiała rano, aby go pruć wieczorem" (N-1 416-417). 
Gąsienica, która pożarłszy świat w wydaniu imaginacyjnym, skazana jest na kanibalistyczną likwidację samej sobie; jakże pasuje ten metaforyczny komentarz Chłędowskiej do podsumowania losu także Flaubertowskiej Emmy.

Bliżej bowarystowskiej fabuły sytuuje się kilkuwątkowe opowiadanie $Z$ historii nie-bohaterów, najdłuższy i według niektórych recenzentów „najdoskonalszy utwór pisarki", umiejętnie podejmujący drażliwy temat zdrady małżeńskiej ${ }^{20}$. „Niebohaterów” spotykamy tutaj w dwóch typowych dla Chłędowskiej odmianach: naiwnych altruistów-dziwaków oraz pasożytów-,jemioły”, które „żywią się najzdrowszymi sokami, a są chorobą drzewa" (N-2 198). Historia warszawskiej pani Bovary, żony bogatego przemysłowca Fechnera, „Julii nerwowej, rozpieszczonej, zaczynającej od poetycznego rozmarzenia, a kończącej na najpospolitszym romansie z hrabiątkiem", to jednak tylko jeden z trzech wątków utworu - drugi dotyczy jej syna Antosia ${ }^{21}$, a trzeci, związany z postacią starego kasjera firmy, został przedstawiony przez samego narratora jako najważniejszy: „piszę bardzo prostą i prawdziwą historię pana Trąbalskiego" (N-2 197).

Biedermeierowski typ sympatycznego poczciwca (poświęcone mu są dwa pierwsze z pięciu rozdziałów, około $1 / 3$ całości tekstu) odgrywa istotną rolę w perypetiach fabularnych, jego postać także otwiera i zamyka historię - na początku widzimy go w przytulnej scenerii kantoru w zażyłej komitywie z kilkuletnim Antosiem Fechnerem, po latach śmierć dorosłego Antoniego, umierającego na rękach kasjera, buduje melodramatyczny finał noweli. Według Ostoi utwór Chłędowskiej „treścią zbytecznie przypomina powieść Daudeta Fromont le jeune et Risler l'aîné", a postać Trąbalskiego ,jest to Risler żywcem przeflancowany na polską niwę" 22 . Faktycznie, fabuły francuska i polska mają wiele pokrewnych elementów: środowisko stołecznego, zamożnego mieszczaństwa (u nowelistki dziwnie pozbawione polskich czy warszawskich realiów), romans nieodpowiedzialnej żony pryncypała czy wspólnika (mężczyzn w obu przypadkach jednako zaślepionych), finansowe perypetie firmy, bezgraniczne poświęcenie wiernego, wieloletniego pracownika, a nawet nieodzowny melodramat finalnej śmierci bohatera. Hipoteza o zapożyczeniu kreacji Trąbalskiego może być po części prawdziwa. Prostoduszny, uczciwy i uczuciowy kasjer Fechnerów pod wieloma wzglę-

${ }_{20}$ Zob. [A n o n i m], Najnowsze wydawnictwa. „Biesiada Literacka” 1885, nr 30, s. 58: „Z historii nie-bohaterów jest najdoskonalszym utworem pisarki, a w literaturze naszej na zawsze zaszczytne zajmie miejsce. Siła talentu prawdziwie męska, kompozycja i technika wytworna, bez zarzutu”. - E. Z oria n [E. S e d l a c z e k], Przeglad literacki. „Kłosy” 1885, nr 1058, s. 155: „Najwyraźniej rysuje się powieść $Z$ historii nie-bohaterów. Plastyka i znajomość charakterów ludzkich podają sobie ręce, aby utworzyć dzieło jakby z życia wykrojone. [...] Obyczajowe i psychiczne studium rozwinęła autorka w tej powieści na szeroką skalę; podjęła temat drażliwy, lecz prawdą drażliwość zmodyfikowała”. Po Pannie Ludwice opowiadanie Z historii nie-bohaterów zebrało najwięcej (obok Świetnych aliansów) komplementów recenzenckich.

${ }^{21} \mathrm{Ch} \mathrm{m}$ i elows k i, który jest autorem przytoczonych tu słów, chwali kreacje matki i syna jako udane (Zarys najnowszej literatury polskiej, s. 295).

${ }^{22}$ O s t oj a, op. cit., s. 25. Nagrodzona przez Akademię Francuską powieść A. D a u det a Fromont jeune et Risler aîné. Mours parisiennes (1874) była wielkim sukcesem i początkiem popularności cenionego później autora. Jej zalety to wiarygodna (choć czasem przerysowana) psychologia postaci i obraz mizerii bytowej rodzin z mieszczańskiej dzielnicy Marais (ciekawe studia społeczno-charakterologiczne). Żądza użycia zakompleksionego kopciuszka z biednej dzielnicy stanowi oś romansowej intrygi. 
dami przypomina technika-rysownika Rislera - łączy ich wrodzona pogoda ducha i potrzeba ładu, niefortunna sytuacja rodzinna, zapalczywa obrona honoru i majątku firmy, a także osoba młodszego brata, przyczyniającego się do ostatecznej katastrofy ${ }^{23}$. Być może, uwagę Chłędowskiej przykuł też paradoks krańcowej dobroci; obaj altruiści w mechanizmie rozkręcającego się bezkarnie zła nie są bez winy, z czego mgliście zdaje sobie sprawę Trąbalski:

Słabość, ustępstwa, ciągłe cofanie się przed podłością ludzką nareszcie przeszły miarę i ściągały na niego pomstę nieba... Może nie myślał tak, jak my piszemy, ale miał instynktowne poczucie prawdy. [N-2 284]

Dramaturgia życia Rislera jest jednak zasadniczo odmienna. Dziecięco ufny introwertyk o duszy artysty i osobowości typowego męża-rogacza, którego nieprawdopodobna naiwność wzbudza w otoczeniu mieszane uczucia i podejrzenia o podłość (Karol Bovary?), nie potrafi się wyzwolić z myszkinowskiej miłości-żałości do upadłej kobiety i jego tragiczne samobójstwo przypomina los Edypa zaplątanego we własne sieci. Dramat życiowy ,niebohatera” Trąbalskiego, poczciwiny o gołębim sercu, nie stoi na tak wysokich koturnach. Mniej naiwny i znowu nie tak bardzo ślepy na ludzkie słabości, nie jest też podmiotem romansowych perypetii; jego sylwetka przypomina raczej inną bliźniaczą postać z powieści Daudeta - kasjera Sigismonda Planusa, równie niezłomnego strażnika honoru i finansów rodziny. W Trąbalskim, jak pisze narrator, wraz z upływającym czasem:

Powoli człowiek nikł - zostawał sługa i urzędnik. Dom Fechnerów pochłaniał tę małą jednostkę.

[...] Jak ślimak do skały, tak on przyrósł do murów fabryki, do ciemnego kantoru [...]. Wielki dom Fechnerów, jako firma kupiecka, jako dom i rodzina, reprezentował w umyśle kasjera jaką̧ś stałość i trwałość [...]. Więc gdy tak kasjer ośm godzin przesiedział w biurze i przez ten czas czuł się śrubką wielkiej, dobrze zorganizowanej maszyny, wracał do domu spokojniejszy, że są na świecie ludzie, którym życie układa się w całość. [...] ponad tym wszystkim górowało jeszcze u niego inne uczucie, [...] wdzięczność i przywiązanie bez granic [...]. [N-2 215-216]

Prywatny świat Trąbalskiego mimo jego permanentnej dobroczynności rozpada się - niesnaski małżeńskie, krnąbrny brat i jego niefortunny ożenek, jego rodzina pozostająca na utrzymaniu kasjera, choroba i śmierć bratowej, niedorozwój jednej bratanicy, kłopoty wychowawcze z drugą, ostateczne wykolejenie się moralne brata i jego córki - to wszystko każe Trąbalskiemu wierzyć, że „,w potopie tego głupiego i bałamutnego życia jeszcze tylko liczby utrzymują się w porządku", bo lepiej rozumie on księgę rachunkową ,niż to, dlaczego życie koło niego plątało się, gmatwało jak kłębek nierozwikłany" (N-2 214, 224). Ale wiara ta zostanie również zachwiana, gdy nadejdzie finansowe zagrożenie firmy: „stary wysłucha całej spowiedzi tej kobiety upadłej a nieszczęśliwej” i we własnych oczach sprze-

${ }^{23}$ U Daudeta finalna intryga wydaje się dość wiarygodna; do samobójczej śmierci Rislera doprowadzają kolejno: ujawnienie wiarołomstwa jego żony i wspólnika, ucieczka wypędzonej małżonki do paryskiego półświatka oraz utrata wiary w jedyną ostoję w życiu, jaką jest brat, również wiarołomny i uwiedziony przez tę samą femme fatale. U Chłędowskiej motyw młodszego brata Trąbalskiego trąci nieco tanią sensacyjnością: nieślubny syn hrabiego, skończony lekkoduch, oszust i obieżyświat, pojawia się, $n b$. w Paryżu, niczym złowróżbne deus ex machina na drodze życiowej młodego Antoniego (w którym stary kasjer, przegrawszy życie, pokłada ostatnią nadzieję), by zabić jedyną latorośl rodu Fechnerów w pojedynku. 
niewierzy się „Bogu i panu Fechnerowi, ojcu i synowi” - ulegając błaganiom żony pryncypała, której namiętność pochłonęła fortunę, z trwogi o honor i spokój domu Fechnerów wyda z kasy brakującą sumę (N-2 281, 283). Wziąwszy winę na siebie, zostanie zesłany na podrzędne stanowisko na prowincji i żyjąc odtąd sporadycznymi wizytami dorastającego Antosia, po latach doczeka śmierci młodego Fechnera z rąk swego własnego, marnotrawnego brata. Ofiara Trąbalskiego przekracza wymiar poświęcenia bohaterów francuskiej powieści; „bezdenność jego niedoli” (N-2 294) nabiera akcentów martyrologicznych, przypominając Balzakowskiego męczennika uczuć rodzinnych, ojca Goriot.

$\mathrm{Na}$ tym jednak wyczerpują się zasadnicze podobieństwa ${ }^{24}$ między utworami Daudeta i Chłędowskiej. Wymowa ich wątków miłosnych jest inna, choć w obu przypadkach można zauważyć odniesienia do Pani Bovary (bodaj nieuniknione u francuskiego autora), jak chociażby osadzenie studium namiętności w kontekście ekonomiczno-finansowym. Ale, jak powiada narrator Daudeta o swojej bohaterce, Sydonia ,nie miała nic z tych sentymentalnych stworzeń à la pani Bovary, co to wracają z teatru z gotowymi frazesami miłości, z konwencjonalnym ideałem" 25 - mąż, później kochanek są dla biednej i próżnej dziewczyny jedynie środkami do osiągnięcia wymarzonego bogactwa, a jej natura kokoty-intrygantki znajduje pełną samorealizację na scenie kabaretu, w świecie krzykliwego blichtru oraz wyzywających gestów. Przedstawiona w lekko mizoginistycznym świetle jako wcielenie grzechu i rozpusty, paryska femme fatale pozbawiona jest głębszego życia psychicznego (jej wnętrze obrazuje etażerka z porcelanowymi figurkami). Z Emmą Bovary łączyć ją mogą tylko pożądanie luksusu, przemyślane aktorstwo, brak zmysłu moralnego oraz... ślepota męża. Jednak Karola Bovary przypomina bardziej mąż romansowej Julii z Historii nie-bohaterów: „kolos o szerokich barkach, na wielkich niezgrabnych nogach, z twarzą poczciwego brytana", w oczach żony „wielki, ciężki parawan, zasłaniający piękny świat” (N-2 229). Historia bohaterki Chłędowskiej nie ma nic wspólnego z awansem społecznym ${ }^{26}$, jest ilustracją bowarystowskiej degrengolady pseudoeterycznych ideałów miłości. Kapryśnie znudzoną żonę warszawskiego fabrykanta, zdegustowaną prozą mieszczańskiego życia Fechnerów, poznajemy w momencie standardowej kuracji „,łłabych nerwów”

${ }^{24}$ Można wyśledzić szereg pomniejszych, jak np. oburzenie Planusa na widok strojnej żony Rislera - niechęć Trąbalskiego do zbytkownych wydatków i bezczynnego życia młodej pani Fechnerowej, mdłe i słabe charaktery kochanków obu kobiet oraz szaleństwa finansowe obu par, ucieczka wiarołomnej żony Rislera do kabaretu u Daudeta - ucieczka krnąbrnej bratanicy Trąbalskiego do baletu, postać idealnej i heroicznej żony wspólnika i wiarołomcy Fromonta - postać gospodarnej i pracowitej żony Fechnera-ojca, albo też rodzajowe obrazki z życia ubogich rodzin czy życiowych bankrutów na paryskich poddaszach; uwaga polskiej nowelistki o tych ostatnich dobrze określa także świat przedstawiony w powieści Daudeta: „Wielką historię spółczesną krzywd socjalnych znają wszyscy; mniej jest znaną historia cicha, podrzędna krzywd indywidualnych... Tu rozbitki, awanturnicy, bankruci moralni nurtują społeczeństwo, dorzucając do tamtego skarbca ludzkiej niedoli ogólnej swój grosz miedziany, fałszywy..." (N-2 313). Podczas gdy u Chłędowskiej dominuje tonacja lekko satyryczno-humorystyczna, u Daudeta koloryt jest bardziej mroczny i (melo)dramatyczny.

25 A. D a u d e t, Fromont jeune et Risler aîné. Mours parisiennes. Paris 1888, s. 49-50: „Ce n'était pas une de ces sentimentales à la Bovary qui reviennent du spectacle avec des phrases d'amour toutes faites, un idéal de convention".

26 Julia „o profilu arystokratycznym” to „obca szlachcianka” w oczach kasjera, ucieleśniającego mieszczańskie cnoty i nieufnego wobec ziemiaństwa (N-2 186). 
we Włoszech. Pobudzona obecnością młodego adoratora, „delikatna, rozpieszczona kobieta" (N-2 246) oddaje się nieokreślonym wrażeniom, do złudzenia przypominającym pulsowanie nastrojów bohaterki Flauberta, często portretowanej w podobnej scenerii leniwego bezruchu i słonecznego, sennego pejzażu.

Julia tak lubi marzyć. Wiele kobiet, tak jak ona, bawi się własnym marzeniem jakby wachlarzem w ciągle zmiennej grze fantazji - raz ten wachlarz roztacza się triumfalnie, raz zwija się, to znowu otwiera, zmienia kierunek, czasem w chwili grymasu leży rozbity, złamany, bez użytku. Dziś jednak Julia nie chce się nawet bawić myślą - przechodzi po jej duszy jakaś chwila zupełnej ciszy, jakby ciężka martwość południowej chwili. Upija się powoli jakimś snem bez treści. Między jej ciemnym, pięknym okiem zwróconym na morze a samym morzem jest związek - przepaść przepaści wzywa. Wszakże i ta dusza kobieca zdaje się schylać nad otchłanią wielką i zatapiać, i kochać tajemnicę, której nie rozumie. Nie rozumie tego wielkiego szumu fal, który wyraża największą klątwę życia - jednostajność, i największe błogosławieństwo życia - także jednostajność... Raz przypływ, a więc konieczne rozbicie o brzeg, raz odpływ, a więc powrót i zatonięcie w wielkiej całości... To jakby historia duszy - przypływ i odpływ między życiem a nieśmiertelnością.

Tego ona nie rozumie; raczej ciągły jęk i żal rozbijającej się fali, to, co się da uchem uchwycić i pod co można podłożyć muzykę własnych uczuć.

Tęskniło jej się żyć... Na brzegu młodego życia widziała dotąd same muszle bez ceny, bez szlachetnej perły miłości.

Nie chce myśleć... Puszcza całą duszę swoją, jakby była suchym liściem, na jednę z tych fal i każe się bujać, kołysać daleko, aż tam, gdzie ciemny szmaragd morza łączy się prawie z widnokręgiem i nie widać już żadnej fali mieniącej się jak srebrna łuska - tam, gdzie z daleka widny statek i smuga pary. Z tą parą chciałaby się ulotnić, unieść wysoko, gdzie by nie doścignął jej ptak, nie zobaczył człowiek, i tak bujać w powietrzu rozdmuchnięta, rozwiana, już nie kobieta, już nie ciało, ale sama dusza, chmurka, para, dym, tchnienie, nic - zgoła nic...

Feliks ziewnął głośno, już wypalił cygaro, przejrzał notatki z rachunkami [...] i rzekł potem ziewając, bardzo znudzony [...]. [N-2 226-228]

I znów poetyka tego fragmentu wydaje się Flaubertowska: nie tylko melanż dyskretnej narracji auktorialnej z monologiem wewnętrznym postaci czy ironiczne zderzenie punktów widzenia żony oraz męża, ale rzadko spotykana u Chłędowskiej poetyzacja wypowiedzi. Znamienne, że obok leniwie marzącej leży ,romans angielski jeszcze nie rozcięty (bo Julia od dawna już nic nie czyta)" (N-2 225); bohaterka najwyraźniej znajduje się na etapie „między lekturą a przyjęciem pozy, jakim jest marzenie", materializując pamięciowe zapasy lekturowe ${ }^{27}$. Jej stan przypomina sentymentalną, platoniczną fazę znajomości Emmy z Leonem oraz pierwszy etap flirtu z Rudolfem - to naiwne rojenia o miłości czystej, z których „spragniona ideału” (N-2 232) Fechnerowa zwierza się przyszłemu kochankowi, to triumf frazesu i konwencjonalnych klisz literackich:

wdzięczny zastęp cieniów poetycznych, delikatnych, na wpół dziecinnych kochanków przesunął się przed jej oczami. [...] Któraż kobieta nie zamarzyła, aby kiedyś, gdy przyciśnie żal i nuda, uklękło u nóg jej takie rycerskie dziecko? Miałaby je zawsze z sobą jak wachlarz, jak książkę nabożną, oprawną w aksamit, jak bombonierkę z atłasu, jak naparstek złoty lub delikatny kryształowy flakonik do ożywczych soli - a kochałby ją w milczeniu, ale do śmierci, nad życie, a bez targu krew by za nią oddał, ale by w żyłach nie miał krwi i namiętności, skarżyłby się do księżyca, tej gwiazdy czystej Dyanny, i pisał wiersze liryczne, a na piersiach nosiłby listek zwiędły z jej wczorajszego bukietu.

Julia wpatrywała się w delikatne rysy młodego chłopca z prawdziwą rozkoszą [...]. [N-2 234-235]

${ }^{27}$ Zob. Pr ze pió r k a, Bowaryzm. Teoria zjawiska w nowym świetle, s. 96. 
Niezbyt szlachetna ,perła miłości”, którą bohaterka wyławia z życia, przechodzi jednak metamorfozę, podobnie jak w przypadku pani Bovary. Jeszcze we włoskiej scenerii, po wyjeździe męża do kraju, Julia odda się swemu Rudolfowi - a jest nim młody hrabia Ludwik, „urodzony tyran mimo swej delikatnej i rozpieszczonej powierzchowności” (N-2 234), zblazowany jedynak, którego związek $\mathrm{z}$ dystyngowaną damą błogosławi własna matka, widząc w nim remedium na synowski nałóg rozpusty. Sceny miłosne zostawi narrator domyślności czytelnika, poprzestając na zarysie sytuacji: rozpalone słońcem dni, kochankowie „sami między niebem a morzem”, milczące wieczory i nocne, ,ciemne niebo jak wielki namiot rozbity nad ich głowami” $(\mathrm{N}-2$ 238, 240). Julia nie jest kochanką triumfującą jak Emma Bovary, prędzej rozczarowaną i upokorzoną - krachem swych dziecięco naiwnych mrzonek o miłości, zwyczajnością partnera, banalnością zła i własną hipokryzją ${ }^{28}$ - niemniej jednak szczęśliwą. Studium stosunku kontynuowanego w Warszawie to najciekawsza psychologicznie partia utworu Chłędowskiej. Niespójną motywację bohaterki thumaczy niekonsekwencja kobiety cierpiącej na syndrom Anny Kareniny. Z jednej strony, mamy skruchę żony i matki, która odruchowo garnie się do dziecka („Widziała jeszcze ratunek w synie”, N-2 243), z drugiej - egoizm bezwolnej kochanki, która pod wpływem partnera stopniowo odsuwa jedynaka od siebie, aż po decyzję wysłania go do szkół za granicę. Antoś, wcielenie spokojnego rozsądku i rzetelności Fechnerów, jest Julii mentalnie obcy, choć należy do dzieci niezwykle uczuciowych. Podświadomy lęk, nienawiść i agresja, jakie żywi (z wzajemnością) wobec hrabiego Ludwika - to klasyczny przypadek freudowskiej zazdrości o matkę, którą chłopiec uwielbia gwałtownie i impulsywnie i do której zajadle broni intruzowi dostępu, ,jak brytan wierny a zły" (N-2 247) ${ }^{29}$. Wprowadzenie perspektywy dziecka dojrzewającego w patologicznej sytuacji rodzinnej, motyw „trudnego dzieciństwa”, rzutującego na cały późniejszy rozwój zapowiadającej się obiecująco osobowości ${ }^{30}$ - to wszystko

${ }^{28}$ Zob. N-2 243: „Powinna być przecież bardzo nieszczęśliwa, aż do ostatnich granic smutku i zniechęcenia, bo jej Ludwik czymże był - jak inni... Ale nie była tak nieszczęśliwą, nareszcie żyła, nic się nie odmieniło; tak samo świeci słońce na niebie; i życie powszednie przechodzi [...], mąż ją kocha, ona z tym mężem żyje i nie odepchnie go od siebie [...]. Więc można żyć z zbrodnią, z grzechem, jak z towarzyszem podróży, codziennym, nieodstępnym; i można uśmiechać się i patrzeć ludziom w oczy! To wszystko ciężkim ołowiem spadło na duszę Julii”.

${ }^{29}$ Najbardziej drastyczna scena, ocierająca się o naturalizm (co jest ciekawe w komparatystycznym zestawieniu z Flaubertem) lub buduarowy romans, ukazuje żywiołowe wtargnięcie chłopca do zaciemnionej sypialni matki i szarpaninę pomiędzy trojgiem; rozjuszony Antoś gryzie w końcu Ludwika w rękę, po czym zostaje wypędzony przez Julię, w której pożądanie zmysłowe - podobnie jak u Emmy Bovary - jest silniejsze niż instynkt macierzyński:

„Pod jego [tj. kochanka] tchnieniem zapalała się jak licha słoma od ognia - od razu, i topniała jak wosk. Była jego stworzeniem: bez woli, bez myśli...

- Wszystko, co chcesz! rzekła teraz, a on ją wziął na ręce i niósł jak dziecko.

- Szczęśliwa jesteś? pytał wśród pieszczot.

- Tak, odparła - i nie kłamała, niestety!” (N-2 257).

Antoś przypomina także postać Sieroży z Anny Kareniny L. Tołstoja: „instynktu dziecka nie oszukać" (N-2 292).

${ }^{30}$ Narracja kilkakrotnie akcentuje intelektualny i emocjonalny potencjał dziecka: „Antoś od dzieciństwa był jakby człowiekiem od razu, spokojnym, statecznym. Był zdolny, szczególniej rachował dobrze [...]” (N-2 215); ,Spokojny chłopiec miewa takie wybuchy namiętnej miłości [do matki], które odsłaniają całą głębokość szczerego serca" (N-2 241). 
ożywia fabularny stereotyp małżeńskiego trójkąta, a podteksty erotyczne są dosyć śmiałe jak na początek dziewiątej dekady XIX wieku. Jeśli mały Antoś, odseparowany od najbliższych, traci poczucie stabilizacji i zaufania - „Żelazna obręcz wiary, miłości pękła w sercu chłopca" (N-2 305) - młody Antoni, porywczy i niezrównoważony, będzie „nosił się w sercu z wewnętrznym kalectwem” (N-2 299), pogardzał kobietami i szukał swego miejsca w radykalnych środowiskach i podejrzanych towarzystwach, gdzie jego krótkie, pozbawione busoli życie znajdzie raptowny, żałosny koniec. Chłędowska nie karze wiarołomstwa dwuznacznym samobójstwem jak Flaubert, potępia je w sposób bardziej jawny i „kobiecy”: zło uderza w niewinnych i najsłabszych ${ }^{31}$. W Pani Bovary perspektywa opuszczonego dziecka została jedynie zasygnalizowana; u polskiej nowelistki dramat starca i dziecka przesłania dramat „słabej” kobiety.

A trzeci akt owego dramatu jest znów porównywalny z ostatnią fazą romansu Emmy (Leon w Rouen), kiedy frenetyczna, wyuzdana zmysłowość ostatecznie zastępuje wcześniejsze rojenia, ubezwłasnowolniając obie kochanki i skazując je na powolną degrengoladę. Gdy w parę miesięcy po zainstalowaniu się Ludwika na posadzie w domu Fechnerów ${ }^{32}$ stosunek kochanków ewoluuje w kierunku monotonnej małżeńskiej rutyny, Julia „,widzi, że zbrodnia przybrała tę samą codzienną liberię powszedniości, dla której znienawidziła cnotę”, tymczasem jej „,marzeniem [...] było - sama nie wiedziała co - ale coś niezwykłego" (N-2 260). Oczywiście, casus Julii nie jest tak wyrafinowany jak pani Bovary; jeśli ta ostatnia do końca jest niewolnicą i zarazem reżyserką swych wyobrażeń o romansie, bohaterka Chłędowskiej (znów podobnie jak Anna Karenina u kresu) przemienia się w niewolnicę wyłącznie mężczyzny.

Już się zupełnie przestała łudzić... Cała sielanka, cała idealność ich miłości zginęła, zdmuchnięta, stracona na zawsze... Kochała już tylko jego po prostu, jego samego, jego włosy, jego oczy, ręce, głos; chciała, aby był blisko niej, zazdrośnie, chciwie. [N-2 261]

jej serce martwiało dla wszystkiego, co nie było Ludwikiem. [N-2 267]

Równocześnie rozczarowanie i przyzwyczajenie generują głód nowych wrażeń. Podczas gdy znudzony Ludwik za pomocą pieniędzy Fechnerów zaspokaja swe nowe pożądania ${ }^{33}$, Julii pozostaje rola upokarzanej i pokornej męczennicy.

Zaczęło się dla niej męczeństwo, ale nie to jednorazowe, co zabija motyla natychmiast

${ }^{31}$ Monolog wewnętrzny młodocianego bohatera w postaci mowy pozornie zależnej wygląda na retorykę samego narratora: „Dlaczego mając w sobie wszystkie instynkta dobre, był łajdakiem? Musiał nim prawie być? Dlaczego?...” (N-2 318). Ostatni rozdział ukazuje studenta Antoniego w Paryżu; relacja o tym w listach matki Ludwika do Julii (tu lekkie akcenty krytyczne wobec środowisk konserwatywnych) to może zaplanowana, finalna symetria postaci obu matek, które dopuściły do wykolejenia swych synów.

32 Wbrew słabej próbie oporu Julii, przy entuzjazmie ślepego męża i ku rozpaczy Trąbalskiego i Antosia. Trójkąt małżeński przypomina nieco relację: doktor Bovary - jego żona - pacjent Rudolf.

${ }^{33}$ Kupuje on miłość tancerki baletu, bratanicy Trąbalskiego - jest to jedna z bardziej udanych intryg fabularnych opowiadania. Postać prymitywnej i pełnej temperamentu Pepity (,Wychowaniem Pepity pokieruje inny mistrz, bez morałów, bez rózgi, bez książki, i ten, który rządzi tabunami dzikich koni na stepie [...]: natura, instynkt”, N-2 211), rezydującej w ,gnieździe kruka”, czyli w brudnej i pełnej błyskotek garderobie, podniecającej Ludwika swoją innością, to jeszcze jedna udana kreacja kobieca i kolejny przykład inklinacji naturalistycznych u Chłę dow s k i ej (N-2 268). 
przekłuciem piersi, to inne, powolne, długie, co go truje stopniowo, statecznie, aż barwa na puszystych, drgających skrzydłach blednie od wielkiej męki...

Humor Ludwika zależał teraz od tego, jak go przyjęła Pepita, lepiej czy gorzej. [N-2 263]

Dlatego też ostatnie momenty rozkoszy Julia gotowa jest opłacić bardzo wysoko, byle od życia i wdzięcznego za pieniądze kochanka wytargować jeszcze trochę niezwykłości:

wszystkie uniesienia miłości, wielkie trwogi, zachwyty, słodycze, wszystko, o czym marzyła od dawna, czego łaknęła konając z głodu, zebrały się w tej jednej chwili, jak się zbierają wszystkie światła niebieskie, płomienie i iskry w krótkim mgnieniu błyskawicy... [N-2 275-276] $]^{34}$

Podobnie jak w przypadku Emmy - „Pieniądze, których [Julia] tak nienawidziła, mściły się wreszcie na niej [...]” (N-2 273). Finansowa pętla nie zaciska się wokół Fechnerowej tylko dzięki ofierze kasjera - postaci rodem z dobrego, biedermeierowskiego świata, postaci, dla której nie ma miejsca w pragmatycznym świecie Flauberta ${ }^{35}$. Pełna lęku i obaw, nieprzespana noc Julii po defraudacji pieniędzy (jeden z udatniejszych epizodów w życiu wewnętrznym postaci Chłędowskiej) stanowi jakiś odpowiednik finalnego rauszu niespokojnej Emmy Bovary. Ocalenie Julii oznacza zresztą jej faktyczną klęskę; ostatnie informacje narratora mówią o kobiecie w średnim wieku, która stara się zatrzymać uciekający czas za pomocą makijażu, szukając po przyjęciach okazji do spotkań z kochankiem; żałośnie wierna, skądinąd także swym marzeniom o wielkiej miłości. Prozaiczny koniec romansu Julii uświadamia, jak wielka dawka postromantycznego patosu ukrywa się w naturalistycznej scenie odejścia Emmy Bovary; ów patos przydaje jej aureoli pokuty i godności. Banalna bohaterka Flauberta, która za pomocą banalnych środków zaspokaja niebanalne tęsknoty, może robić wrażenie postaci tragicznej, mimo odautorskiej ironii. Banalna Julia nie ma na to szans; auktorialna narracja Chłędowskiej nie ukrywa irytacji i potępiającego dystansu ${ }^{36}$. Dlatego historia warszawskiej pani Bovary ześlizguje się $\mathrm{w}$ stronę buduarowego romansu $\mathrm{z}$ elementami dydaktyki, choć próbki ciekawszych rozwiązań fabularnych oraz niepozbawionych niuansów analiz psychologicznych z pewnością zasługują na uznanie.

Dla dzisiejszego czytelnika najciekawiej spośród bowarystowskich historii Chłędowskiej przedstawia się, być może, nowela Babie lato ${ }^{37}$. Tekst ujawnia najlepsze cechy eklektycznej techniki narracji, jaką wypracowała Chłędowska: lekki ton gawędziarski, akcenty autotematyczne i humorystyczny dystans wobec posta-

${ }^{34}$ Niepohamowane pożądanie zmysłowe i rozluźnienie seksualne to punkt, do którego docierają obie, niepomne na przyzwoitość bohaterki: i Julia, i Emma Bovary pod koniec upodabniają się do kobiet lekkich obyczajów.

${ }^{35}$ Postaci takie natomiast (Risler, Planus) istnieją u Daudeta; w swoim słowie wstępnym do francuskiej powieści Leconte de Lisle słusznie podkreśla enigmatyczny związek twórczości Daudeta z naturalizmem, choć pisarz był zaliczany do grona uczniów Zoli.

${ }^{36}$ Po histerycznym wymuszeniu finansowej machinacji na kasjerze Julia ,wybiegła już lekka, prawie swobodna i wesoła, bo w tej naturze słabej uczucia, jak kwiaty zgięte burzą, podnosiły się prędko" (N-2 282). Wydaje się, że osąd autorki nie jest zbyt odległy od słów zrozpaczonego męża po odkryciu rujnujących wydatków żony: „Jesteś głupią! [...] Nie jesteś kobietą, jesteś niczym!”, choć narrator zastrzega się, iż u Feliksa ,natura gminna, prosta, wzięła zupełnie górę” (N-2 273). Dla mentalności mieszczańskiej istotą „kobiecości” była gospodarna przezorność, nie kobiece powaby.

37 Oprócz anonimowego recenzenta ([A n o n i m], Silva rerum) wyróżniał tę nowelę jedynie C h m i e lo w s k i (Chtędowska; Zarys najnowszej literatury polskiej). 
$\mathrm{ci}^{38}$, ironiczno-gorzkie spuentowanie „komedii ludzkiej”, elementy rzeczowej analizy psychologicznej, a także pozbawiony sentymentalizmu liryzm ( $n b$. poetycka wieloznaczność tytułu). Choć powieść Flauberta zostaje tu mimochodem przywołana explicite (bohater rozprawia „o różnych typach kobiecych, [...] o Wenus z Milo, o pani Bovary", N-2 357), Amelia w mniejszym stopniu przypomina Emmę niż postaci opisane wcześniej. Flaubertowską paralelę usprawiedliwia przede wszystkim dość subtelna tkanka akcji wewnętrznej oraz kolejny scenariusz demaskacji stereotypów miłosnych. Zafiksowanie kobiecej psychiki na dziewczęcych marzeniach w przypadku trzydziestokilkuletniej Amelii zostaje ocenione najsurowiej ze wszystkich trzech bowarystowskich bohaterek: „w ostach i kwasach familijnego życia zakonserwowało się jej szesnastoletnie pensjonarskie serce, tak naiwne - powiedzmy po prostu - tak głupie, jak przed laty...” (N-2 345). Tym razem bohaterka ma godnego protagonistę $\mathrm{w}$ postaci bowarystowskiego partnera. Kolejny okaz męskiego egoizmu ${ }^{39} \mathrm{w}$ nowelistyce Chłędowskiej to młody filozof $\mathrm{i}$,,esteta" Witold, u którego „,zawsze w wrażeniach [...] tło musiało być literackie” (N-2 249):

Żył na pożyczanych wzorach, modelując się na typach wziętych z książek [...].

Od czasu do czasu wcielał się w literackie cudzoziemskie postacie.

Sztuczna maska prawie mu przyrosła do twarzy: już przeszedł kilka takich metampsychoz; był Faustem, był panem de Camors ${ }^{40}$, a obecnie żył w skórze Mussetowskiego bohatera z Confessions d'un enfant du siècle. [N-2 368]

Ale pozujący na chore dziecię wieku miłośnik Schopenhauera nie utrzymuje do końca swej roli. Zblazowany i rozczarowany do kobiet, traktuje zrazu spotkaną w górskim kurorcie znajomą sceptycznie; potem zajęty autoanalizą malkontent widzi w pełnej naturalnej prostoty Amelii powiernicę swych niepokojów; wreszcie odkrywszy, że stał się obiektem poważnego uczucia, po pierwszym oszołomieniu (a raczej zachwycie z powodu nieodpartego uroku swej osoby) egocentryk rezygnuje z łatwej zdobyczy i salwuje się ucieczką, przerażony żarliwą bezkompromisowością oraz deklaracją ,na zawsze” niedoszłej kochanki. Melodramatyzm kluczowej sceny staje się przedmiotem subtelnej ironii; stereotypowe gesty i teatralizacja marzenia całkowicie pokrywają się $\mathrm{z}$ autentycznym przeżyciem bohaterki:

Na jego zapewnienie miłości podniosła ręce wysoko nad głową.

- Mego męża już nie ma! - zawołała w najwyższej egzaltacji.

Witold uczuł, że go zimny dreszcz przejmuje od stóp do głowy.

Nagle przeszyła go myśl, że może jej mąż [...] nie żyje.

- Nie ma go w sercu moim! - wołała w uniesieniu - patrz!

Zerwała z palca obrączkę ślubną, podniosła ją tak, że złoto chwilę zamigotało w świetle księżyca, i rzuciła daleko w wodę.

Potem pochyliła się nad ciemną otchłanią wód tajemniczych.

- Nie mam już żadnych obowiązków - rzekła oddychając ciężko - nie mam przeszłości, ty jesteś dla mnie wszystkim... pierwszym, jedynym, ostatnim! [N-2 381]

${ }^{38} \mathrm{~Np} . \mathrm{N}-2$ 349: „Trochę mnie to kosztuje powiedzieć, że Witold wcale nie był zakochany w Amelii”; „To nam tylko psuje romansowość sytuacji [...]”.

${ }_{39}$ Zob. N-2 371: „O, ludzki egoizmie! szkaradny, brutalny, ale szczerze ludzki”. O s t o j a (op. cit., s. 25) widziała w takich kreacjach męskich Chłędowskiej pewną regułę: „Mężczyźni mniej udają się pani Chłędowskiej, uwydatnia głównie u nich jedną stronę - egoizm. W nim znajduje motor prawie wszystkich postępów, uczuć, zboczeń, a czyni to nawet z rodzajem przyjemności i jakby miała urazę do całej płci męskiej i odkrywała jej słabą stronę z rozkoszą".

${ }_{40}$ Bohater wyróżnionej przez Akademię Francuską powieści O. F e u ille ta Monsieur de Camors (1867; wyd. polskie: Hrabia de Camors, 1869). 
Pikanterii banalnej sytuacji dodaje fakt, iż Witold, zdegustowany płytkimi miłostkami, jakich doznał do tej pory, teraz nie tylko odrzuca ,ideał”, ale całkowicie wypiera go ze swej świadomości - biorąc na rzeczywistości odwet za własną niedojrzałość:

Takie nieszczęście tylko jemu przytrafić się mogło [...]. [N-2 382]

Poświęcenie? namiętność?!... miał ochotę płakać jak dziecko w złości.

Po prostu nic nie czuł, czym by odpłacić mógł za wielką jej miłość serdeczną. [N-2 383]

obowiązkiem jego było raczej [...] uratować ją od samej siebie. Honor mu to nakazywał, honor, który tym razem spotykał się z samolubstwem na szerokiej, bezpiecznej drodze wygody.

$[\ldots]$

W książce „o miłości”, którą wydał w rok później i która się bardzo podobała niektórym przerafinowanym krytykom, największe powodzenie miał ustęp, [...] gdzie autor z wielką siłą i ogniem występował przeciw kobietom w ogóle i zaprzeczał istnieniu wszelkiej miłości wyższej. [N-2 384]

W przypadku Witolda bowaryzm zatacza procesualne koło: lektura-marzenie/ poza - lektura (tutaj zastąpiona produkcją literacką). Dzięki wątkowi „męskiej” myśli analitycznej, skonfrontowanej z bezrefleksyjną „kobiecą” emocją, nowela Babie lato urasta do rangi swoistego metatekstu, gdzie romans podlega autotematyzacji (dialogi i monologi bohaterów, „książka o miłości”). Wypada też zauważyć, iż puentująca utwór scena odjazdu Witolda przypomina do złudzenia ucieczkę Rudolfa; w momencie gdy nie spodziewająca się niczego protagonistka roi o przyszłym szczęściu, słyszy nowinę o przyjeździe męża i odjeździe ukochanego, który pozostawił dla niej list. Skojarzenie ze sceną u Flauberta - kiedy Emma (z listem pożegnalnym od kochanka w kieszeni) musi spożywać z mężem obiad przy stole, podczas gdy za oknem przemyka pędzący powóz Rudolfa - jest nieodparte. Otwarte, stonowane i symboliczne zakończenie utworu korzystnie wyróżnia go na tle jaskrawo melodramatycznych finałów nowel wcześniejszych.

Właśnie w tej chwili rozległ się w oddaleniu odgłos ciężkiego pojazdu, ruszającego $\mathrm{z}$ miejsca.

$[\ldots]$

Przez chwilę słychać było turkot kół; smutna nuta trąbki pocztarskiej [!] to się zbliżała, to oddalała według kierunku drogi, ginęła powoli, aż się rozwiała zupełnie w ciszy mglistego poranku... [N-2 385-386]

Niedoszły kochanek Amelii nie przypomina wprawdzie cynicznego Rudolfa, niemniej jednak otacza go - jako wcielenie „brutalnego”, męskiego egoizmu skandalizująca aura, swoisty PR kobieciarza i „gagatka”, jak nazywa go jedna z eks-kochanek (N-2 371, 340).

Stereotypowo genderowe rozpisanie tej romansowej tragikomedii jest godne uwagi. Amelia bowiem to kreacja pokrewna jednej z literackich sióstr pani Bovary: bohaterce sztandarowej, feministycznej powieści Kate Chopin Przebudzenie z roku 1889. Podobnie jak Amerykanka Edna, heroina Chłędowskiej jest ubezwłasnowolnioną, potulną małżonką tudzież matką kilku synów. Po raz pierwszy opuszcza zaborczy klan rodziny męża i podczas kuracji spędzając całe dnie na powietrzu, chłonie niczym Edna nowe impulsy oraz wrażenia. I jak tamta rodzi się do nowego życia - świadomej kobiecości:

Inna z niej kobieta, inne spojrzenie, uśmiech i głos inny.

$[\ldots]$ 
Od razu pękły zawiasy, rygle, kraty więzienia; była wolna, swobodna, sam na sam z naturą. [N-2 344]

Po prostu nie żyła dotąd: życiem choćby zwierzęcia, tego ptaka, co się kąpie w promieniu słońca. $[\ldots]$

$[\ldots]$

Teraz wszystkie struny [serca] poruszały się od razu i brzmiały, jakby rozszalałe.

- Żyć! - zawołała [...]. [N-2 346]

I podobnie do bohaterki kreolskiego romansu „Amelcia, budząca się nagle do życia, jak zaklęta księżniczka po długim letargu" (N-2 350), budzi się, jak wskazuje sam tytuł noweli, po raz ostatni. Owa delikatnie nostalgiczna tonacja nadaje całej historii niewątpliwie sporo uroku.

Po długim skołataniu następowała w jej sercu cisza, ukojenie, któremu się poddała bez dalszej walki, tym więcej, że na dnie tego szczęścia była wielka melancholia.

Był to piękny dzień jesienny, przed samym zachodem słońca.

Amelia patrzała na tę ziemię obumierającą, a strojną jak do wesela i patrzała w głąb własnej duszy. Zdaje się, jakoby jesień powtarzała wiosnę.

$[\ldots]$

Teraz nad łąkami wloką się nitki pajęcze, zaczepiają o wszystko, bez celu, ale je rozerwać łatwiej, niż oderwać!

$[\ldots]$

Cicho, ciepło... w jej sercu i na ziemi... Łabędzia to pieśń natury, najpiękniejsza, bo smutna; ostatnia przed zimą. [N-2 370-371]

Wcześniej narracja dokładnie rejestruje wszystkie etapy tego przebudzenia, przy czym wskazać można szereg motywów wspólnych dla noweli Chłędowskiej oraz dla powieści Chopin: obecność (młodszego) adoratora - katalizatora metamorfozy, nieumiejętność lekkiego podejścia do flirtu, wyprawy z partnerem w sérénité natury i zmysłowe rozkoszowanie się bezkresnym pejzażem, przebudzenie się namiętności, falowanie nastrojów między zapalczywością, kaprysem a zniechęceniem, gesty radykalnego zerwania z przeszłością. Relacje Edny z mężczyznami są bardziej skomplikowane, lecz i ją opuszcza wybranek - w przekonaniu, iż czyni to dla jej dobra ${ }^{41}$. Znamienne, że w Babim lecie motywacji małżeńskiej zdrady nie wartościuje się negatywnie, a bohaterka nie jest traktowana tak ironicznie jak ,impresjonistka” czy tak krytycznie jak romansowa Julia. Dramat „bezbronnego, starego dziecka" (N-2 385) zostaje ukazany z dystansem, ale też z empatią oraz ze zrozumieniem dla kobiecego aktu wyzwolenia i odreagowania małżeńsko-rodzinnej monotonii. I podczas gdy wiarygodność historii „impresjonistki” Filomeli sytuuje się na granicy prawdopodobieństwa, a wiarołomna i zmysłowa Julia jest kreacją zbyt papierową - bohaterka Babiego lata, w całej swej przeciętności, udatnie i bez nadmiernego dydaktyzmu ilustruje przegraną infantylnych marzeń z determinizmem faktów; przy czym jej historia obciążona zostaje podobną ambiwalencją aksjologiczną, co przypadek Emmy Bovary. Wreszcie, tak jak wcześniej Historia nie-bohaterów, także Babie lato eksploatuje postromantyczne klisze krajobrazowe, którymi operują bohaterowie Flauberta, Emma i Leon: morze oraz góry. Pejzaż morza jako ikona namiętności Julii i Ludwika mógłby korespon-

${ }^{41}$ Finalna, niejednoznacznie samobójcza śmierć bohaterki Przebudzenia powtarza schemat Flaubertowski; pozostawienie opuszczonych kobiet na pastwę życia w fabułach Chłędowskiej znów można uznać za bardziej obiektywne. 
dować z modernistyczną obrazowością powieści Chopin, gdzie kluczowy lejtmotyw buduje symbolika oceanu (żywiołu, jedni bytu, nirwanicznego zapomnienia) - gdyby nie fakt, iż u Chłędowskiej obraz zdaje się także konotować otchłań grzechu (,z tym szumem fal gniewnych i żałośnych jakby wielka otchłań, gdzie wszystko ginie", N-2 240). Pejzaż gór z kolei stereotypowo towarzyszy wszelkim „wzlotom” akcji wewnętrznej w Babim lecie, tworząc dla nich lekko ironiczny kontrapunkt.

Czy „bowarystowskie” fabuły polskiej nowelistki wzbogacają w zasadniczy sposób kulturowo-literacki model zjawiska? Zapewne nie. Ale bez nich polska beletrystyka drugiej połowy XIX wieku byłaby może uboższa. Oprócz wyraźnej funkcji rozrywkowej i dydaktycznej teksty Chłędowskiej dokumentują w jakimś stopniu recepcję kluczowych dla (post)nowoczesności motywów: rozczarowania, znudzenia, banalnej lekkości bytu czy poszukiwania tożsamości. A jej pseudoflaubertowskim bohaterom z pewnością nie brak wyróżnika, w którym badacze dopatrują się kwintesencji bowaryzmu - ,przejmującej nieraz i głębokiej samowiedzy”, „wyższych aspiracji” połączonych ze świadomością „błędu, połowiczności, obioru fałszywej drogi" ${ }^{2}$.

\section{A bstract}

ANETA MAZUR

(University of Opole)

\section{STEFANIA CHŁĘDOWSKA'S SHORT STORY TRIPTYCH - A LOST LINK IN POLISH "BOVARISM?"}

Three psychological and customary studies by Stefania Chłędowska (1850-1884), an obscure novelist, namely Impresjonistka (Impressionist), Z historii nie-bohaterów (From the History of Non-heroes), Babie lato (Indian summer) are original paraphrases of Flaubert's bovarism. The references to French model are seen in the method of characters' presentation, as well as on the fictional, stylistic and partially worldview level. Neurotic and bored heroines from upper class suffer from bovaristic hunger of sensual-psychical impressions and existential disappointment, while their adulterous affairs result in traumatic experience, and spiritual or physical destruction. The short stories' auctorial tone includes an ironic distance from the world presented in them, pseudoromance melodrama as well as naturalistic accents (in the case of From the History of Non-heroes patterned after Alphonse Daudet's novel Fromont jeune et Risler aîné (Fromont Junior and Risler Senior〉).

\footnotetext{
${ }^{42} \mathrm{M}$ a z a n, Bowaryzm w literackich transpozycjach polskich modernistów, s. 21, 24.
} 